\title{
Riotous connections?
}

\section{Roxy Cavalcanti, Carlie Goldsmith, Lynda Measor and Peter Squires review research into the experiences, connections and disconnections, of young people}

A s Robert Reiner remarked during a recent Howard League lecture, the August 2011 riots in England became something of a criminological Rorschach test insofar as almost every commentator tended to see in them a vindication of their own particular perspectives and concerns. This has been so largely irrespective of the quality of evidence (if any) they considered. A number of the earlier more political forays into the field of riot accounting collapsed quickly as a more sophisticated and, crucially, properly evidenced, picture began to emerge. Suggestions that the riots were the work of 'feral' and 'disconnected' or underclass youth, or were 'gang inspired' or even (rather perplexingly) a consequence of insufficiently robust policing, soon fell by the wayside as the evidence about those arrested, charged and prosecuted began to mount (The Guardian, 2011; Morrell et al., 2011).

\section{Rhetoric \\ Of course, none of this was sufficient to de-rail the government's new anti-gang strategy, rolled out even as the Home Secretary was lowering - to 13 per cent - the police estimates of 'gang involved' young people thought to have been caught up in the rioting. In any event, 'gang-involvedness' is always a very particular construction of police intelligence processing. As the evidence rolled in it became increasingly difficult to sustain the early, unfortunately rather bi-partisan and scarcely original, rhetorics about 'mindless people' and 'simple criminality' uttered by David Lammy, MP and David Cameron, Prime Minister.}

It is here that the 'riot commentaries' coincide directly with a piece of research, part of the Arts and Humanities Research Council (AHRC) 'Connected Communities' programme, upon which we have been engaged for most of the year. Our project has involved reviewing the social science evidence concerning the 'disconnected youth' phenomenon which has become such a sizeable and well-travelled discourse in the USA. The UK has not been immune from this particular interpretation of the context and condition of young, urban, working class youth. The idea is closely associated with the NEET label (not in employment, education or training - the only 'connections' which count?) and the notions of 'dark social capital' (Fisher and Gruescu, 2011), apparently the little millstones of personal negative equity surrounding supposedly underqualified young people undermining their employability and increasing their disaffection.

\section{Connecting the riots}

Exploring these varying problem discourses and comparing and contrasting them with the research evidence on 'youthful connections' both with and within communities, it was fascinating to see these same discourses recycled, once again, in August's 'riot talk'. Accordingly, young people's presumed attitudes and moral sensibilities, their behaviour and cultures - in short, their perceived 'disconnection' from mainstream community - was prioritised and problematised out with any sense of the contexts and experiences of their lives; without reference to any research evidence; and, always a giveaway, without any investigation of their own understandings and perceptions - although that evidence is now beginning to emerge.

It is important to be clear here, for in 'connectedness' as in many other matters of public policy, questions of distributional justice arise. Like community safety, or 'social capital' itself, the ability of some groups to secure their positions may come with costs for others. The redistribution of victimisation in 'unequal Britain' is a particularly relevant example of this growing inequality (Hope, 2001). Likewise, good connections for some may spell barriers to others. Even so the research evidence we surveyed does not reveal a relentless tale of 'youth disconnection'; the picture may be nuanced, but it is still quite clear.

\section{Lived experiences and youthful connections}

The research tells a complex story about how young people can be both connected to and disconnected from different aspects of 'community'. This analysis challenges dominant accounts which suggest that supposedly 'irresponsible' or 'disrespectful' young people simply erode a sense of community or pose threats to community members.

On the contrary, young people demonstrate varying forms of agency, resilience and psycho-social attachment which underpin their connections to close friends, family and extended peer groups. Much research shows that young people consider themselves to be relatively well connected to their communities. This is particularly evident in established communities, such as social housing estates where resident populations are fairly stable. Family and friends often provide the connections through which mutual aid is given and organised.

Connection to neighbourhood networks is vital for young people. A safe place to stay, food, money, clothes, formal and informal, legal and illegal, employment or economic opportunities, and childcare can be available to the 'connected'. Indeed, it is argued that, for young people living in socially 
and economically distressed neighbourhoods, the absence, or withdrawal, of official support and services has often made such informal connections the only way to survive'.

Connections can be formed or reinforced, through advantageous sexual liaisons or by making 'links' or using the language of 'family', territorial or identity affiliations (for example peer group memberships - even 'gangs' or 'crews'). Use of public space is often critical to many young people's experiences; it represents perhaps the dominant site outside the home, where peer connections can be sustained. Engagement in forms of 'risky' or illegal behaviour can also strengthen friendship bonds or mutual obligations, while involvement in both 'social', and 'anti-social' activities are ways in which young people participate in community life whether 'off the books' or 'below the radar' of legitimacy. Obviously, however, potentially harmful consequences can accompany these peer to peer connections, including personal dangers and risks, confrontations with rivals, and criminalising encounters with the police and the law.

\section{'Street cultures'}

Clearly, such 'street cultures' are not without their difficulties; the resulting behaviours can be highly problematic, harmful and disruptive for communities, and, not least, for other young people, but even so these forms of collective action nonetheless represent attempts to establish security, opportunity, identity and belonging where few viable alternatives exist. They are attempts at 'government from below'. Even when the values espoused and the behaviour exhibited clashes violently with the formal values of mainstream 'civilised' society including the values held by many other people (young and old) in their own communities, they are, nonetheless, products of that very same society.

However, whilst some young people negotiate particular connections within their communities, research shows they are often disconnected from official public agencies, employment structures and other institutions such as schools and official agencies, this is seldom a consequence of a lack of effort. The lives led by young people and the strategies they adopt are often misunderstood by both social welfare and criminal justice professionals. Labelling an area as 'crime prone' by official agencies can lead to young people experiencing persistent discrimination, school exclusion, police targeting and other negative stereotyping.

\section{Disconnection to demonisation?}

Such evidence directly engages with the emerging discourses of the August Riots and a number of issues become clearer. Notions of 'simple criminality' and 'mindless violence' become quite untenable. The young people caught up in the various riot-related activities are, if anyone cares to ask them, quite capable of giving an account of themselves. Neither are they 'disconnected'; rather they largely share many of the aspirations of many others of their generation although they are often amongst those who have had the least opportunity to achieve these goals. Nor are they simply the passive 'victims' of mob rule in the heat of the moment and an insufficiency of police, rather their agency is demonstrated in precisely the ways that young people the length and breadth of the country exercise it: in part opportunism, in part bravado, in part peer pressure, in part recklessness or retaliation for perceived grievances and so on. Many undoubtedly participated in the rioting for precisely the kinds of reasons that others held back; reasons that are rooted in their connections with one another, and their disconnections and disenchantments with aspects of society and community.

Disenchantment runs like a thread throughout the 'riot commentaries'. One reason why politicians were so anxious to discredit the rioting may be that they recognised something of the legitimacy of these claims. Only
Kenneth Clarke, as Justice Secretary, saw fit to connect the high proportion of rioters with previous convictions to what he called the 'broken criminal justice system'. For here, finally, lies another link with our own research. At the conclusion of our evidence survey we reported the main themes to a series of community groups and sought their views. Deprived and disadvantaged young people were not perceived as a class apart; nor did they feel 'disconnected' from community. The testimonies arising outlined not so much a 'broken society', but told of 'broken promises', a withdrawal of opportunities, the retreat of welfare and the advent of a more disciplinarian public policy. A palpable loss of social justice seemed central. In this regard, just as 'the riots' provoke many backwards glances to earlier phases in our riot-prone history, a riot inquiry from some 20 years ago provides a clue to our present difficulties. For as Lord Woolf concluded in his report on the prison riots of 1990 (Woolf and Tumin, 1990), without justice, security and control are nothing.

Roxy Cavalcanti is a Research Officer, Lynda Measor is a Reader and Professor Peter

Squires is a Lecturer, all at the University of Brighton. Carlie Goldsmith is a Lecturer in Criminology, Kingston University

The research project referred to in this article was funded by the AHRC Connected Communities Programme.

\section{References}

Fisher, D. and Gruescu, S. (2011). Children and the Big Society: Backing communities to keep the next generation safe and happy, ResPublica.

The Guardian (2011), Reading the riots: Investigating England's Summer Disorder, www.guardian.co.uk/uk/series/readingthe-riots

Hope, T. (2001), 'Crime victimisation and inequality in risk society', in Matthews, R. and Pitts, J. (eds.) Crime, Disorder and Community Safety, London: Routledge.

Morrell, G., Scott, S., McNeish, D. and Webster, S. (2011), The August Riots in England. Understanding the involvement of young people, London: NatCen.

Woolfe, Lord. and Tumin, S. (1990), Prison disturbances April 1990. Report of an inquiry. London: The Stationery Office. 